\title{
PEMANFAATAN IKAN GABUS (Ophiocephalus striatus) MENJADI BAKSO DALAM RANGKA PERBAIKAN GIZI MASYARAKAT DAN UPAYA MENINGKATKAN NILAI EKONOMISNYA
}

\author{
Deny Utomo, Rekna Wahyuni, Rakhmad Wiyono \\ Staf Pengajar Fakultas Pertanian Universitas Yudharta Pasuruan \\ email : denyut369@gmail.com
}

\begin{abstract}
Abstrak: Penelitian ini bertujuan untuk memperoleh perbandingan proporsi ikan gabus dan tepung tapioka yang tepat sehingga diperoleh bakso ikan gabus yang berkualitas baik secara fisik, kimia dan organoleptik serta mengetahui aspek kelayakan finansial produksi bakso ikan gabus skala industri kecil.

Hasil penelitian tahap I menunjukkan perlakuan terbaik adalah perlakuan tapioka $70 \%$ dan ikan gabus 30\% dengan kadar air 49,27\%, kadar abu $10,365 \mathrm{mg} / 100 \mathrm{~g}$, tekstur 13,05 N, kadar pati 18,805\%, kadar lemak $1,7675 \%$, kadar protein 22,8275\%, kesukaan : warna 5,95 (mendekati suka), kekenyalan 5,35 (antara agak suka sampai suka), aroma 6,4 (antara suka sampai sangat suka) dan rasa 5,45 (antara agak suka sampai suka).

Hasil penelitian tahap II menghasilkan perhitungan aspek finansial produk bakso ikan gabus skala industri kecil yang berkapasitas produksi 118 g bakso ikan gabus / hari layak secara finansial dengan kriteria-kriteria sebagai berikut: PBP sebesar 4,941 tahun, Net $\mathrm{BC}$ ratio= 1,223, $\mathrm{RCR}=1,372$, NPV (pada suku bunga pinjaman 15\%) = Rp. 8.659.111,91, IRR $=16,53 \%, \mathrm{BEP}=$ 4.851,86 unit atau Rp. 37.775.000,08 atau 6,9\%.
\end{abstract}

Kata Kunci : Bakso Ikan Gabus

\section{PENDAHULUAN}

Ikan merupakan sumber pangan hewani yang sudah dikenal berbagai lapisan masyarakat di berbagai belahan negara. Di Indonesia, ikan merupakan sumber protein yang banyak dikonsumsi saat ini, mengingat sumber protein hewani lain seperti daging sapi sangat mahal yaitu Rp. 50.000/kg, sedangkan daging ayam yang relatif lebih murah banyak ditakuti masyarakat karena merebaknya kasus flu burung.
Mahalnya harga-harga produk pangan sumber protein hewani dibarengi meningkatnya kasus gizi buruk di Indonesia menyebabkan perlunya mencari alternatif sumber protein yang murah. Alternatif sumber protein hewani yang saat ini memungkinkan untuk dikembangkan adalah ikan gabus (Ophiocephalus striatus) atau di Jawa dikenal sebagai ikan "kutuk". Ikan gabus merupakan ikan yang banyak terdapat secara alami di sungai-sungai dan bendungan serta belum pernah dibudidayakan. Nilai gizi 
ikan gabus cukup tinggi, yaitu protein sebesar $42 \%$, lemak $1,7 \%$, dan juga mengandung berbagai mineral dan vitamin $\mathrm{A}$; dengan demikian ikan gabus sangat potensial untuk dikembangkan dalam industri pangan.

Pengolahan ikan gabus perlu dilakukan untuk lebih meningkatkan nilai komersial ikan gabus dan memperpanjang umur simpan. Berbagai teknologi pengolahan produk ikan telah banyak dilakukan, antara lain pembuatan nuggets, berbagai jenis sosis, abon maupun bakso; namun pengolahan ikan yang relatif paling sederhana, murah, tidak membutuhkan bahan-bahan kimia tambahan dan mudah dilakukan oleh rumah tangga adalah bakso. Bakso juga merupakan jenis makanan yang sudah umum dikenal baik dikota bahkan di pelosokpelosok pedesaan, terjangkau oleh berbagai kalangan ekonomi dan digemari oleh berbagai lapisan usia; berbeda dengan nuggets dan sosis yang selama ini lebih dikenal sebagai produk pangan untuk kalangan menengah keatas.

Untuk memperoleh produk bakso ikan gabus yang berkualitas dan disukai konsumen, maka proses pembuatan bakso harus diperhatikan. Faktor yang terutama sangat mempengaruhi kualitas bakso adalah jumlah penambahan tapioka, oleh karena itu perbandingan proporsi ikan dan tepung tapioka yang tepat perlu diteliti sehingga didapatkan bakso ikan gabus yang berkualitas baik dari karakteristik fisik, kimia dan tentunya disukai konsumen.
Kelayakan finansial produksi bakso ikan gabus skala rumah tangga pun perlu dikaji apakah menguntungkan atau tidak, mengingat bahwa pada saat ini tingkat inflasi dan suku bunga selalu naik turun dan usaha skala rumah tangga biasanya sangat rentan terhadap perubahan-perubahan tersebut.

\section{TINJAUAN PUSTAKA \\ Ikan Gabus (Ophiocephalus striatus)}

Ikan gabus merupakan ikan karnivora yang suka memakan hewan lain yang lebih kecil, seperti cacing, udang, ketam, plankton dan udang renik (Djuhanda, 1981).

Jenis-jenis ikan keluarga

Ophiocephalus adalah ikan gabus, tomang, kerandang, yang hampir ditemukan di seluruh wilayah Indonesia.

Suprayitno (2006) Protein ikan gabus segar mencapai 25,1\%, sedangkan $6,224 \%$ dari protein tersebut berupa albumin. Jumlah ini sangat tinggi dibanding sumber protein hewani lainnya. Albumin merupakan jenis protein terbanyak di dalam plasma yang mencapai kadar 60 persen dan bersinergi dengan mineral $\mathrm{Zn}$ yang sangat dibutuhkan untuk perkembangan sel maupun pembentukan jaringan sel baru seperti akibat luka dan penyembuhan luka akibat operasi. Selain itu, kadar lemak ikan gabus relatif rendah dibandingkan kadar lemak jenis-jenis ikan lain (tongkol $24,4 \%$ dan lele $11,2 \%$ lemak) memungkinkan umur simpan ikan gabus lebih panjang karena 
kemungkinan mengalami ketengikan lebih lama.

\section{Bakso}

Bakso adalah salah satu bentuk olahan restrukturisasi daging yang merupakan produk pangan berbentuk bola atau yang lain, yang diperoleh dari campuran daging / ikan yang telah dihaluskan dengan cara digiling (kadar daging/ikan minimal 50\%) dan pati atau serealia dengan atau tanpa penambahan bahan-bahan kimia lain serta bahan tambahan makanan yang diijinkan (SNI, 1995).

Menurut Hardoko (1994) daging ikan sebagai bahan utama pembuatan bakso merupakan sumber protein myofibril yang membentuk gel. Sedangkan pati yang ditambahkan berfungsi sebagai pembentuk sekaligus memperbaiki adonan, meningkatkan daya ikat air dan memperbaiki tekstur.

Kriteria mutu untuk tekstur bakso adalah tekstur kompak, elastis, tidak ada serat daging, tidak ada duri dan tulang, tidak basah berair dan rapuh (Wibowo, 1999). Proses pengikatan ini merupakan suatu reaksi yang dipengaruhi oleh pemanasan, karena daging dalam keadaan segar (Hardoko, 1994).

Proses pembuatan bakso ikan meliputi: pencucian ikan segar, pemisahan daging ikan dari duri dan jerohan, penggilingan, penirisan, pencampuran dengan tepung tapioka dan bumbu-bumbu yaitu bawang putih, merica, gula, garam, MSG yang telah dihaluskan; kemudian pencetakan berbentuk bola, perendaman dalam air hangat $40^{\circ} \mathrm{C} \quad 15$ menit, perebusan sampai mengapung (matang) dan penirisan (Wibowo, 1999).

\section{Tepung Tapioka}

Pengolahan ubi kayu (Manihot esculenta, Crantz) menjadi tepung tapioka dalam industri makanan Indonesia sebesar 19,7 \% dari total industri (Anonim, 2006).

Jones dan Amos (1967) dalam Saraswati (1986) mengatakan bahwa pati yang berasal dari ubikayu yaitu tapioka merupakan bahan dasar pembuatan kerupuk. Penggunaan tapioka dalam pembuatan kerupuk didasarkan atas kemampuan daya kembang yang tinggi dibandingkan dengan jenis tepung lainnya. Tapioka mengandung amilosa $17 \%$ dan amilopektin $83 \%$ dengan ukuran granula 3-3,5 mikron, dengan nisbah amilosa-amilopektin cukup tinggi sehingga proses penyerapan air selama pemasakan juga meningkat.

\section{METODE PENELITIAN \\ Rancangan Percobaan}

Penelitian ini merupakan penelitian eksperimental dengan satu variable bebas yaitu proporsi penambahan tepung tapioka dan tujuh variable tergantung yaitu kadar pati, kadar protein, kekenyalan, warna, tekstur, aroma dan rasa. Rancangan pecobaan menggunakan Rancangan Acak Kelompok factor tunggal.

\section{Prosedur Penelitian}

a. Analisis proksimat daging ikan
gabus 
Ikan gabus dicuci bersih dan diambil sample daging secukupnya untuk dilakukan analisis proksimat yang meliputi: kadar air, kadar protein, kadar lemak, tekstur, kadar pati dan kadar abu. Masing-masing analisis dilakukan tiga kali (triplo) untuk memperoleh nilai rata-rata $(\mathrm{x})$ dan simpangan baku $\left(\mathrm{S}_{\mathrm{d}}\right)$.

b. Pembuatan bakso ikan gabus

\section{Pengumpulan Data}

Pengumpulan data dilakukan dengan melakukan analisis karakteristik kimia yaitu kadar pati dan kadar protein; karakteristik fisik yaitu kekenyalan dan karakteristik organoleptik yaitu kesukaan terhadap warna, tekstur, aroma dan rasa. Data yang meliputi karakteristik kimia dan fisik diperoleh dari laboratorium, sedangkan data karakteristik organoleptik diperoleh dari pengisian skor kesukaan oleh panelis minimal 20 orang. Skala nilai kesukaan mulai dari 1 (sangat tidak suka) sampai 7 (sangat suka).

\section{Analisis Data}

Analisis ragam dilakukan untuk mengetahui adanya pengaruh perlakuan perbandingan proporsi daging ikan dan tepung tapioka terhadap kadar pati, kadar protein, kekenyalan, warna, tekstur, aroma dan rasa.

Apabila dari hasil analisis ragam terdapat pengaruh perlakuan maka dilanjutkan dengan Uji Beda Duncan (Duncan Multiple Range Test) terhadap data kuantitatif ( kadar protein, kadar pati dan kekenyalan) untuk mengkaji perlakuan mana yang berbeda nyata.
Untuk parameter-parameter bersifat kualitatif yaitu kesukaan warna, tekstur, aroma dan rasa dilakukan analisis ragam dengan metode Friedman (Basker, 1988).

\section{Pengambilan Keputusan}

Pengambilan Keputusan dilakukan untuk menentukan perlakuan mana yang terbaik dengan mempertimbangkan ke tujuh variable tergantung tersebut. Metode pengambilan keputusan yang dipergunakan adalah Metode Indeks Efektivitas (De Garmo, 1980).

\section{Analisis Kelayakan Finansial dan Analisis Sensitivitas}

Analisis kelayakan finansial dilakukan terhadap perlakuan proporsi ikan gabus dan tepung tapioka yang terpilih berdasarkan tahap 5 diatas. Kriteria-kriteria kelayakan finansial yang akan diukur meliputi (Husnan dan Suwarsono, 1991) :

- Net Present Value

- Break Even Point (kg, Rp)

- Internal Rate of Return

- Payback Period

Sedangkan analisis sensitivitas dilakukan untuk mengetahui pengaruh perubahan-perubahan variabel eksogen (asumsi-asumsi) terhadap keputusan investasi, yaitu sampai seberapa jauh variabel-variabel eksogen tersebut (naik/turun) dapat ditolerir tanpa merubah keputusan investasi. Variabelvariabel eksogen yang dipertimbangkan:

1. penurunan penerimaan penjualan 
2. Kenaikan Biaya Operasional

3. Penurunan Penerimaan dan Kenaikan Biaya

\section{HASIL DAN PEMBAHASAN Kadar Air}

Kadar air bakso ikan gabus berkisar antara 46,72\% (tapioka 90\% dan ikan gabus 10\%) hingga 53,21\% (tapioka $40 \%$ dan ikan gabus 60\%). Grafik hubungan antara perlakuan proporsi tapioka dan ikan gabus dengan kadar air bakso ikan dapat dilihat pada Gambar 1.

Gambar 1 menunjukkan bahwa semakin rendah proporsi tapioka dan semakin tinggi ikan gabus menyebabkan makin tingginya kadar air bakso, dengan mengikuti pola persamaan linear $\mathrm{y}=1,1705 \mathrm{x}+45,546$. koefisien regresi sebesar 94,98\% menunjukkan bahwa perlakuan proporsi ikan gabus dan tapioka mempunyai pengaruh besar terhadap kadar air bakso ikan

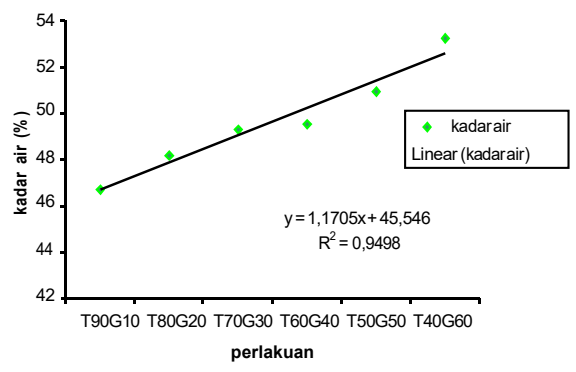

Gambar 1. Hubungan antara perlakuan proporsi tapioka dan ikan gabus dengan kadar air
Tabel 1 menunjukkan rerata kadar air akibat perlakuan proporsi ikan gabus dan tapioka.

Tabel 1. Kadar Air Bakso Ikan Gabus

\begin{tabular}{|c|r|}
\hline Perlakuan & \multicolumn{1}{c|}{ Kadar Air } \\
\hline Tapioka $90 \%$ - ikan gabus $10 \%$ & $46,7175 \mathrm{c}$ \\
\hline Tapioka $80 \%$ - ikan gabus $20 \%$ & $48,1975 \mathrm{bc}$ \\
\hline Tapioka $70 \%$ - ikan gabus $30 \%$ & $49,27 \mathrm{~b}$ \\
\hline Tapioka $60 \%$ - ikan gabus $40 \%$ & $49,51 \mathrm{~b}$ \\
\hline Tapioka 50\% - ikan gabus $50 \%$ & $50,9525 \mathrm{~b}$ \\
\hline Tapioka 40\% - ikan gabus $60 \%$ & $53,21 \mathrm{a}$ \\
\hline
\end{tabular}

Keterangan: Angka yang didampingi huruf yang sama menunjukkan tidak berbeda pada $\operatorname{taraf} \alpha 5 \%$

Tabel 1 menunjukkan bahwa kadar air bakso tertinggi adalah akibat perlakuan Tapioka 40\% - ikan gabus $60 \%$, sedangkan kadar air terendah adalah akibat perlakuan Tapioka 90\% ikan gabus $10 \%$ dan tidak berbeda nyata dengan perlakuan Tapioka $80 \%$ ikan gabus $20 \%$. Tampak pada Tabel 3 bahwa makin rendah kadar tapioka dan makin tinggi ikan gabus menyebabkan makin tinggi kadar air bakso. Hal ini berkaitan dengan proses gelatinisasi pati yang terkandung dalam tapioka dan pembentukan ikatan silang antara pati dengan protein yang telah mengalami denaturasi. Eskin et al. (1971) dalam Wibowo (1999) menyatakan bahwa reaksi gelatinisasi pati dan denaturasi protein menyebabkan air terperangkap dalam matriks kompleks pati-protein, sedangkan gelatinisasi pati tersebut terjadi pada suhu relatif tinggi (lebih dari $60^{\circ} \mathrm{C}$ ) menyebabkan granula pati 
membengkak terisi air. De Mann (1997) menyatakan bahwa adanya molekul-molekul protein yang tinggi dalam bahan makanan akan mengikat uap air dengan baik; hal ini karena kemampuan ikat air dari asam amino rantai samping yaitu hidrokarbon. Hal ini mengakibatkan bakso dengan proporsi ikan gabus yang lebih tinggi menghasilkan bakso dengan kadar air yang lebih tinggi pula.

\section{Kadar Abu}

Kadar abu bakso ikan gabus berkisar antara 10,205\% (tapioka 90\% dan ikan gabus 10\%) hingga 10,5175\% (tapioka 40\% dan ikan gabus 60\%). Grafik hubungan antara perlakuan proporsi tapioka dan ikan gabus dengan kadar abu bakso ikan dapat dilihat pada Gambar 2.

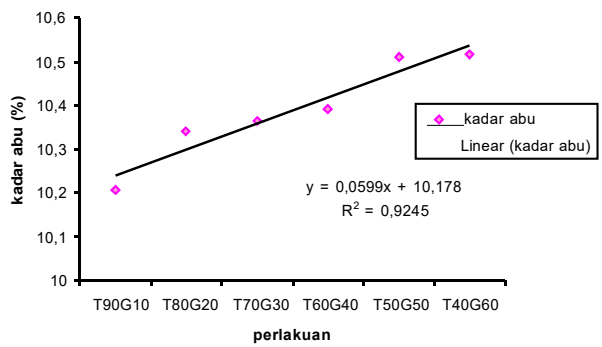

Gambar 2. Hubungan antara perlakuan proporsi tapioka dan ikan gabus dengan kadar abu

Gambar 2 menunjukkan bahwa semakin rendah proporsi tapioka dan semakin tinggi ikan gabus menyebabkan makin tingginya kadar abu bakso, dengan mengikuti pola persamaan linear $\mathrm{y}=0,0599 \mathrm{x}+10,178$. koefisien regresi sebesar 92,45\% menunjukkan bahwa perlakuan proporsi ikan gabus dan tapioka mempunyai pengaruh besar terhadap kadar abu bakso ikan. Tabel 2 menunjukkan rerata kadar abu akibat perlakuan proporsi ikan gabus dan tapioka.

Tabel 2 menunjukkan bahwa kadar abu bakso tertinggi adalah akibat perlakuan Tapioka $40 \%$ - ikan gabus $60 \%$ meskipun tidak berbeda dengan Tapioka 50\% - ikan gabus 50\% maupun Tapioka $60 \%$ - ikan gabus $40 \%$, sedangkan kadar abu terendah adalah akibat perlakuan Tapioka 90\% ikan gabus $10 \%$.

Tabel 2. Kadar Abu Bakso Ikan Gabus

\begin{tabular}{|c|r|}
\hline Perlakuan & $\begin{array}{c}\text { Kadar } \\
\text { Abu }\end{array}$ \\
\hline Tapioka $90 \%$ - ikan gabus $10 \%$ & $10,205 \mathrm{~b}$ \\
\hline Tapioka $80 \%$ - ikan gabus $20 \%$ & $10,34 \mathrm{ab}$ \\
\hline Tapioka $70 \%$ - ikan gabus $30 \%$ & $10,365 \mathrm{ab}$ \\
\hline Tapioka $60 \%$ - ikan gabus $40 \%$ & $10,39 \mathrm{a}$ \\
\hline Tapioka $50 \%$ - ikan gabus $50 \%$ & $10,51 \mathrm{a}$ \\
\hline Tapioka $40 \%$ - ikan gabus $60 \%$ & $10,5175 \mathrm{a}$ \\
\hline
\end{tabular}

Keterangan: Angka yang didampingi huruf yang sama menunjukkan tidak berbeda pada $\operatorname{taraf} \alpha 5 \%$

Tampak pada Tabel 2 bahwa makin rendah kadar tapioka dan makin tinggi ikan gabus menyebabkan makin tinggi kadar abu bakso. Hal ini berkaitan dengan kandungan alami mineral yang terkandung dalam ikan gabus. Hadiwiyoto (1993) menyatakan bahwa ikan gabus mengandung beberapa mineral yaitu Zinc sebesar $1,74 \mathrm{mg} / 100 \mathrm{~g}$, Besi 0,9 mg/100 g, 
Kalsium 62,0 mg/100 g dan Fosfor 176 $\mathrm{mg} / 100 \mathrm{~g}$.

\section{Tekstur}

Tekstur bakso ikan gabus berkisar antara 10,05 N (tapioka 90\% dan ikan gabus $10 \%$ ) hingga $17,025 \mathrm{~N}$ (tapioka $40 \%$ dan ikan gabus 60\%). Grafik hubungan antara perlakuan proporsi tapioka dan ikan gabus dengan tekstur bakso ikan dapat dilihat pada Gambar 3.

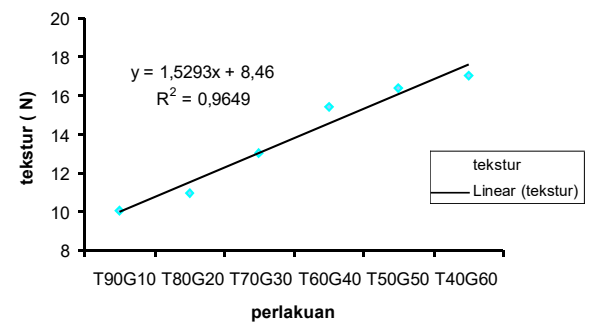

Gambar 3. Hubungan antara perlakuan proporsi tapioka dan ikan gabus dengan tekstur

Gambar 3 menunjukkan bahwa semakin rendah proporsi tapioka dan semakin tinggi ikan gabus menyebabkan makin tingginya tekstur bakso, dengan mengikuti pola persamaan linear $\mathrm{y}=1,5293 \mathrm{x}+8,46$. koefisien regresi sebesar 96,49\% menunjukkan bahwa perlakuan proporsi ikan gabus dan tapioka mempunyai pengaruh besar terhadap tekstur bakso ikan. Tabel 3 menunjukkan rerata tekstur akibat perlakuan proporsi ikan gabus dan tapioka.
Tabel 3. Tekstur Bakso Ikan Gabus

\begin{tabular}{|l|r|}
\hline \multicolumn{1}{|c|}{ Perlakuan } & \multicolumn{1}{c|}{ Tekstur } \\
\hline Tapioka $90 \%$ - ikan gabus $10 \%$ & $10,05 \mathrm{~d}$ \\
\hline Tapioka $80 \%$ - ikan gabus $20 \%$ & $10,95 \mathrm{~d}$ \\
\hline Tapioka $70 \%$ - ikan gabus $30 \%$ & $13,05 \mathrm{c}$ \\
\hline Tapioka $60 \%$ - ikan gabus $40 \%$ & $15,425 \mathrm{~b}$ \\
\hline Tapioka $50 \%$ - ikan gabus $50 \%$ & $16,375 \mathrm{ab}$ \\
\hline Tapioka $40 \%$ - ikan gabus $60 \%$ & $17,025 \mathrm{a}$ \\
\hline
\end{tabular}

Keterangan: Angka yang didampingi huruf yang sama menunjukkan tidak berbeda pada taraf $\alpha 5 \%$

Tabel 3 menunjukkan bahwa tekstur bakso tertinggi adalah akibat perlakuan Tapioka $40 \%$ - ikan gabus $60 \%$ meskipun tidak berbeda dengan Tapioka 50\% - ikan gabus 50\%, sedangkan tekstur terendah adalah akibat perlakuan Tapioka 90\% - ikan gabus $10 \%$ dan tidak berbeda dengan Tapioka $80 \% \quad$ - ikan gabus $20 \%$.Tampak pada Tabel 3 bahwa makin rendah kadar tapioka dan makin tinggi ikan gabus menyebabkan makin tinggi tekstur bakso, atau bakso makin kenyal sehingga butuh energi lebih besar untuk menekannya. Hal ini berkaitan dengan pembentukan matriks antara pati dan protein selama proses pemasakan. Pada matriks terebut terdapat ikatan silang antara protein yang telah terdenaturasi dan pati yang mengalami gelatinisasi. Muchtadi dkk (1988) menyatakan bahwa ikatan saling silang antara pati dan protein merupaka ikatan ionik dan kovalen sehingga membentuk tekstur yang kuat, sedangkan gelatinisasi pati tanpa adanya protein membentuk jembatan hidrogen yang lebih ikatannya lebih 
lemah dan berakibat pda tekstur yang lebih lunak (Hardoko, 1994).

\section{Kadar Pati}

Kadar pati bakso ikan gabus berkisar antara 22,65\% (tapioka 90\% dan ikan gabus 10\%) hingga 14,7\% (tapioka 40\% dan ikan gabus 60\%). Grafik hubungan antara perlakuan proporsi tapioka dan ikan gabus dengan kadar pati bakso ikan dapat dilihat pada Gambar 4.

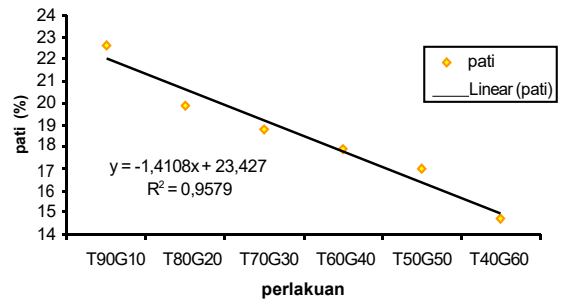

\section{Gambar 4. Hubungan antara perlakuan proporsi tapioka dan ikan gabus dengan kadar pati}

Gambar 4 menunjukkan bahwa semakin rendah proporsi tapioka dan semakin tinggi ikan gabus menyebabkan makin tingginya kadar pati bakso, dengan mengikuti pola persamaan linear $\mathrm{y}=-1,4108 \mathrm{x}+$ 23,427. koefisien regresi sebesar 95,79\% menunjukkan bahwa perlakuan proporsi ikan gabus dan tapioka mempunyai pengaruh besar terhadap kadar pati bakso ikan. Tabel 4 menunjukkan rerata kadar pati akibat perlakuan proporsi ikan gabus dan tapioka.
Tabel 4. Kadar Pati Bakso Ikan Gabus

\begin{tabular}{|c|r|}
\hline Perlakuan & $\begin{array}{c}\text { Kadar } \\
\text { Pati }\end{array}$ \\
\hline Tapioka $90 \%$ - ikan gabus $10 \%$ & $22,6525 \mathrm{~d}$ \\
\hline Tapioka $80 \%$ - ikan gabus $20 \%$ & $19,8975 \mathrm{c}$ \\
\hline Tapioka $70 \%$ - ikan gabus $30 \%$ & $18,805 \mathrm{bc}$ \\
\hline Tapioka $60 \%$ - ikan gabus $40 \%$ & $17,8825 \mathrm{~b}$ \\
\hline Tapioka 50\% - ikan gabus 50\% & $17 \mathrm{~b}$ \\
\hline Tapioka 40\% - ikan gabus $60 \%$ & $14,7 \mathrm{a}$ \\
\hline
\end{tabular}

Keterangan: Angka yang didampingi huruf yang sama menunjukkan tidak berbeda pada taraf $\alpha 5 \%$

Tabel 4 menunjukkan bahwa kadar pati bakso terrendah adalah akibat perlakuan Tapioka 40\% - ikan gabus $60 \%$, sedangkan kadar pati tertinggi adalah akibat perlakuan Tapioka $90 \%$ - ikan gabus $10 \%$. Tampak pada Tabel 4 bahwa makin rendah kadar tapioka dan makin tinggi ikan gabus menyebabkan makin rendah kadar pati bakso, sebaliknya makin tinggi kadar tapioka dan makin rendah kadar ikan gabus menyebabkan makin tingginya kadar pati yang diperoleh. Hal ini karena tapioka memang merupakan sumber pati (amilum) yang berasal dari singkong, sehingga makin banyak proporsi pati mengakibatkan makin tingginya kadar pati. Saraswati menyatakan bahwa kandungan karbohidrat (yaitu pati) dalam tapioka adalah sebesar $88,2 \mathrm{~g}$ per $100 \mathrm{~g}$ bahan.

\section{Kadar Lemak}

Kadar lemak bakso ikan gabus berkisar antara 1,535\% (tapioka 90\% dan ikan gabus 10\%) hingga 1,9825\% (tapioka 40\% dan ikan gabus 60\%). Grafik hubungan antara perlakuan 
proporsi tapioka dan ikan gabus dengan kadar lemak bakso ikan dapat dilihat pada Gambar 5.

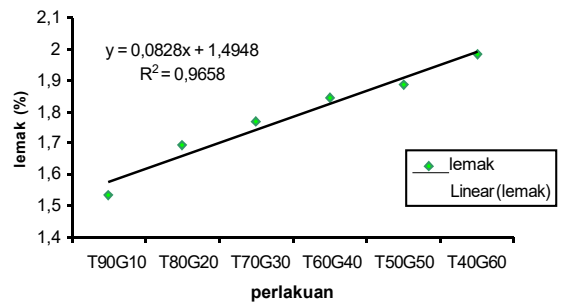

Gambar 5. Hubungan antara perlakuan proporsi tapioka dan ikan gabusdengan kadar lemak

Gambar 5 menunjukkan bahwa semakin rendah proporsi tapioka dan semakin tinggi ikan gabus menyebabkan makin tingginya kadar lemak bakso, dengan mengikuti pola persamaan linear $\mathrm{y}=0,0828 \mathrm{x}+1,4948$. koefisien regresi sebesar 96,58\% menunjukkan bahwa perlakuan proporsi ikan gabus dan tapioka mempunyai pengaruh besar terhadap kadar lemak bakso ikan. Tabel 5 menunjukkan rerata kadar lemak akibat perlakuan proporsi ikan gabus dan tapioka.

Tabel 5 menunjukkan bahwa kadar lemak bakso tertinggi adalah akibat perlakuan Tapioka 40\% - ikan gabus $60 \%$, sedangkan kadar lemak tertinggi adalah akibat perlakuan Tapioka 90\% ikan gabus $10 \%$. Tampak pada Tabel 5 bahwa makin rendah kadar tapioka dan makin tinggi ikan gabus menyebabkan makin tinggi kadar lemak bakso, sebaliknya makin tinggi kadar tapioka dan makin rendah kadar ikan gabus menyebabkan makin rendahnya kadar lemak yang diperoleh. Hal ini karena ikan gabus, sebagaimana kelompok ikan pada umumnya, memang mengandung lemak, sebagaimana dinyatakan oleh Hadiwiyoto (1993) bahwa kandungan lemak ikan gabus adalah sebesar 2,7 g / $100 \mathrm{~g}$ bahan. Sedangkan tapioka juga mengandung lemak namun relatif lebih sedikit yaitu 0,5 g / $100 \mathrm{~g}$ bahan (Saraswati, 1986) sehingga kandungan lemak ikan jelas lebih berpengaruh terhadap kadar lemak bakso.

Tabel 5. Kadar Lemak Bakso Ikan Gabus

\begin{tabular}{|l|r|}
\hline Perlakuan & $\begin{array}{c}\text { Kadar } \\
\text { Lemak }\end{array}$ \\
\hline Tapioka $90 \%$ - ikan gabus $10 \%$ & $1,535 \mathrm{~d}$ \\
\hline Tapioka $80 \%$ - ikan gabus $20 \%$ & $1,6925 \mathrm{c}$ \\
\hline Tapioka $70 \%$ - ikan gabus $30 \%$ & $1,7675 \mathrm{bc}$ \\
\hline Tapioka $60 \%$ - ikan gabus $40 \%$ & $1,8425 \mathrm{~b}$ \\
\hline Tapioka $50 \%$ - ikan gabus $50 \%$ & $1,8875 \mathrm{~b}$ \\
\hline Tapioka $40 \%$ - ikan gabus $60 \%$ & $1,9825 \mathrm{a}$ \\
\hline
\end{tabular}

Keterangan: Angka yang didampingi huruf yang sama menunjukkan tidak berbeda pada taraf $\alpha 5 \%$

\section{Kadar Protein}

Kadar protein bakso ikan gabus berkisar antara 20,3025\% (tapioka $90 \%$ dan ikan gabus 10\%) hingga 27,205\% (tapioka 40\% dan ikan gabus $60 \%$ ). Grafik hubungan antara perlakuan proporsi tapioka dan ikan gabus dengan kadar protein bakso ikan dapat dilihat pada Gambar 6. 


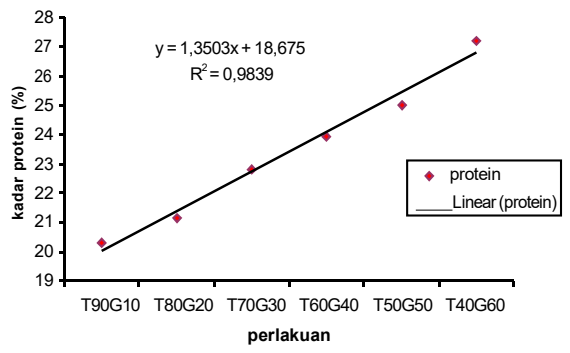

Gambar 6. Hubungan antara perlakuan proporsi tapioka dan ikan gabus dengan kadar protein

Gambar 6 menunjukkan bahwa semakin rendah proporsi tapioka dan semakin tinggi ikan gabus menyebabkan makin tingginya kadar protein bakso, dengan mengikuti pola persamaan linear $\mathrm{y}=1,3503 \mathrm{x}+18,675$. koefisien regresi sebesar 98,39 \% menunjukkan bahwa perlakuan proporsi ikan gabus dan tapioka mempunyai pengaruh besar terhadap kadar protein bakso ikan. Tabel 8 menunjukkan rerata kadar protein akibat perlakuan proporsi ikan gabus dan tapioka.

Tabel 6 menunjukkan bahwa kadar protein bakso tertinggi adalah akibat perlakuan Tapioka 40\% - ikan gabus $60 \%$, sedangkan kadar protein tertinggi adalah akibat perlakuan Tapioka $90 \%$ - ikan gabus 10\% meskipun tidak berbeda dengan Tapioka $80 \%$ - ikan gabus $20 \%$.
Tabel 6. Kadar Protein Bakso Ikan Gabus

\begin{tabular}{|c|r|}
\hline Perlakuan & $\begin{array}{c}\text { Kadar } \\
\text { Protein }\end{array}$ \\
\hline Tapioka $90 \%$ - ikan gabus $10 \%$ & $20,3025 \mathrm{e}$ \\
\hline Tapioka $80 \%$ - ikan gabus $20 \%$ & $21,1325 \mathrm{e}$ \\
\hline Tapioka $70 \%$ - ikan gabus $30 \%$ & $22,8275 \mathrm{~d}$ \\
\hline Tapioka $60 \%$ - ikan gabus $40 \%$ & $23,92 \mathrm{c}$ \\
\hline Tapioka 50\% - ikan gabus $50 \%$ & $25,0175 \mathrm{~b}$ \\
\hline Tapioka $40 \%$ - ikan gabus $60 \%$ & $27,205 \mathrm{a}$ \\
\hline
\end{tabular}

Keterangan: Angka yang didampingi huruf yang sama menunjukkan tidak berbeda pada taraf $\alpha 5 \%$

Tampak pada Tabel 6 bahwa makin rendah kadar tapioka dan makin tinggi ikan gabus menyebabkan makin tinggi kadar protein bakso, sebaliknya makin tinggi kadar tapioka dan makin rendah kadar ikan gabus menyebabkan makin rendahnya kadar protein yang diperoleh. Hal ini karena ikan gabus, sebagaimana kelompok ikan pada umumnya, memang merupakan sumber protein, sebagaimana dinyatakan oleh Hadiwiyoto (1993) bahwa kandungan protein ikan gabus adalah sebesar 25,2 g / 100 g bahan. Suprayitno (2003) menyatakan bahwa dalam protein ikan gabus terkandung albumin yang cukup tinggi. Sedangkan tapioka juga mengandung protein namun relatif lebih sedikit yaitu 1,1 g / $100 \mathrm{~g}$ bahan (Saraswati, 1986) sehingga kandungan protein ikan jelas lebih berpengaruh terhadap kadar protein bakso.

\section{Kesukaan Kekenyalan}

Kesukaan kekenyalan bakso ikan gabus berkisar antara 3,15 yaitu antara agak tidak suka hingga ragu-ragu (tapioka 90\% dan ikan gabus 10\%) 
hingga 6,05 yaitu antara suka hingga sangat suka (tapioka 40\% dan ikan gabus 60\%). Grafik hubungan antara perlakuan proporsi tapioka dan ikan gabus dengan Kesukaan kekenyalan bakso ikan dapat dilihat pada Gambar 7.

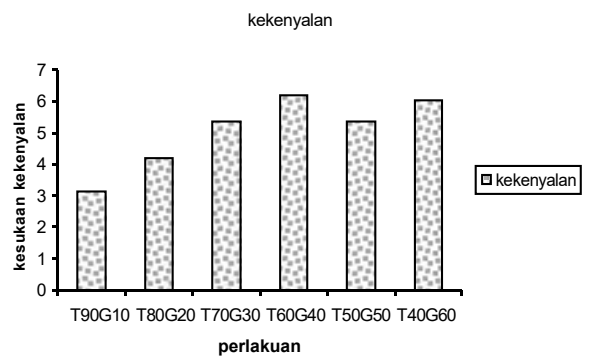

Gambar 7. Hubungan antara perlakuan proporsi tapioka dan ikan gabus dengan kesukaan kekenyalan

Gambar 7 menunjukkan bahwa semakin rendah proporsi tapioka dan semakin tinggi ikan gabus menyebabkan makin tingginya kesukaan terhadap kekenyalan bakso. Kesukaan kekenyalan tampak semakin meningkat apabila proporsi tapioka menurun dan proporsi ikan gabus ditingkatkan. Tabel 9 menunjukkan jumlah rangking kesukaan kekenyalan akibat perlakuan proporsi ikan gabus dan tapioka. Tapioka $60 \%$ - ikan gabus $40 \%$ dan Tapioka 40\% - ikan gabus $60 \%$ memiliki skor kesukaan kekenyalan yang hampir sama.
Tabel 7. Kekenyalan Bakso Ikan Gabus

\begin{tabular}{|c|r|}
\hline Perlakuan & $\begin{array}{c}\text { Jumlah } \\
\text { rangking } \\
\text { kesukaan } \\
\text { kekenyalan }\end{array}$ \\
\hline Tapioka $90 \%$ - ikan gabus $10 \%$ & $22.5 \mathrm{c}$ \\
\hline Tapioka $80 \%$ - ikan gabus $20 \%$ & $41.5 \mathrm{c}$ \\
\hline Tapioka $70 \%$ - ikan gabus 30\% & $74.5 \mathrm{~b}$ \\
\hline Tapioka $60 \%$ - ikan gabus $40 \%$ & $107.0 \mathrm{a}$ \\
\hline Tapioka 50\% - ikan gabus 50\% & $73.5 \mathrm{~b}$ \\
\hline Tapioka $40 \%$ - ikan gabus $60 \%$ & $101.0 \mathrm{a}$ \\
\hline
\end{tabular}

Keterangan: Angka yang didampingi huruf yang sama menunjukkan tidak berbeda pada taraf $\alpha 5 \%$

Tabel 7 menunjukkan bahwa kesukaan kekenyalan bakso tertinggi adalah akibat perlakuan Tapioka 40\% ikan gabus $60 \%$, dan tidak berbeda dengan Tapioka $60 \%$ - ikan gabus $40 \%$, sedangkan kesukaan kekenyalan terendah adalah akibat perlakuan Tapioka $90 \%$ - ikan gabus 10\% meskipun tidak berbeda dengan Tapioka $80 \%$ - ikan gabus $20 \%$.

Tampak pada Tabel 7 bahwa makin rendah kadar tapioka dan makin tinggi ikan gabus menyebabkan makin tinggi kesukaan kekenyalan bakso, sebaliknya makin tinggi kadar tapioka dan makin rendah kadar ikan gabus menyebabkan makin rendahnya kekenyalan yang diperoleh. Kesukaan terhadap kekenyalan makin tinggi apabila daging ikan gabus yang ditambahkan makin banyak karena teksturnya padat, sedangkan tapioka yang makin tinggi disertai ikan yang makin rendah menyebabkan kesukaan kekenyalan menurun karena tekstur bakso lebih lembek dan lengket, kurang 
padat. Fungsi daripada tapioka sebenarnya adalah "filler" sekaligus "binder"untuk membantu terbentuknya tekstur bakso (Wibowo, 1999), apabila tidak ada tapioka sama sekali maka saat dipanaskan bakso akan pecah sedangkan apabila tapioka terlalu banyak maka terjadi penyerapan air yang berlebih oleh tapioka saat pemanasan sehingga bakso jadi lembek. Secara kimiawi, dengan adanya pencampuran daging ikan dengan tapioka pada proporsi yang tepat maka akan terbentuk matriks kompleks protein - pati selama proses pemanasan, dimana pada saat itu terjadi peristiwa gelatinisasi pati dan denaturasi protein yang selanjutnya kedua komponen saling membentuk ikatan silang (Hardoko, 1994).

\section{Kesukaan Warna}

Kesukaan warna bakso ikan gabus berkisar antara 4,95 yaitu cenderung agak suka (tapioka $40 \%$ dan ikan gabus 60\%) hingga 5,95 cenderung suka (tapioka $70 \%$ dan ikan gabus $30 \%$ dan tapioka $60 \%$ dan ikan gabus $40 \%$ ). Grafik hubungan antara perlakuan proporsi tapioka dan ikan gabus dengan Kesukaan warna bakso ikan dapat dilihat pada Gambar 8.

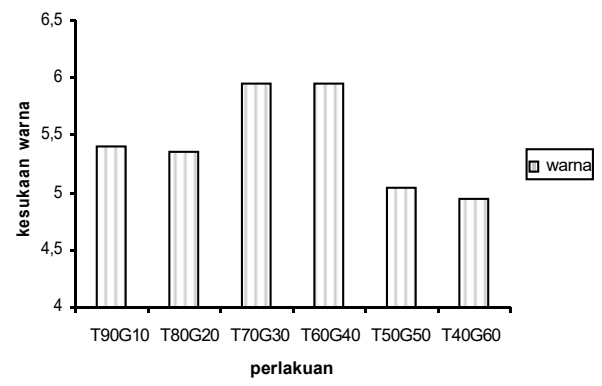

Gambar 8. Hubungan antara perlakuan proporsi tapioka dan ikan gabus dengan kesukaan warna

Gambar 8 menunjukkan bahwa kesukaan warna tertinggi adalah perlakuan Tapioka 70\% - ikan gabus $30 \%$ dan Tapioka $60 \%$ - ikan gabus $40 \%$. Tapioka yang cenderung tinggi masih lebih disukai warnanya daripada ikan gabus yang terlalu tinggi. Tabel 8 menunjukkan jumlah rangking kesukaan warna akibat perlakuan proporsi ikan gabus dan tapioka.

Tabel 8. Warna Bakso Ikan Gabus

\begin{tabular}{|l|r|}
\hline \multicolumn{1}{|c|}{ Perlakuan } & $\begin{array}{c}\text { Jumlah } \\
\text { rangking } \\
\text { kesukaan } \\
\text { warna }\end{array}$ \\
\hline Tapioka $90 \%$ - ikan gabus $10 \%$ & $73.0 \mathrm{~b}$ \\
\hline Tapioka $80 \%$ - ikan gabus $20 \%$ & $66.0 \mathrm{~b}$ \\
\hline Tapioka $70 \%$ - ikan gabus $30 \%$ & $90.5 \mathrm{a}$ \\
\hline Tapioka $60 \%$ - ikan gabus $40 \%$ & $90.5 \mathrm{a}$ \\
\hline Tapioka $50 \%$ - ikan gabus $50 \%$ & $51.0 \mathrm{bc}$ \\
\hline Tapioka $40 \%$ - ikan gabus $60 \%$ & $49.0 \mathrm{c}$ \\
\hline
\end{tabular}

Keterangan: Angka yang didampingi huruf yang sama menunjukkan tidak berbeda pada taraf $\alpha 5 \%$

Tampak pada Tabel 8 bahwa Tapioka $70 \%$ - ikan gabus $30 \%$ dan Tapioka $60 \%$ - ikan gabus $40 \%$ lebih 
disukai warnanya daripada perlakuan lainnya. Namun perlakuan dengan tapioka cenderung tinggi dan ikan gabus rendah masih lebih disukai warnanya daripada perlakuan dengan ikan gabus tinggi dan tapioka rendah. Hal ini karena tapioka cenderung tinggi dan ikan gabus rendah menghasilkan bakso dengan warna yang cenderung pucat / terang, sedangkan perlakuan dengan ikan gabus tinggi dan tapioka rendah menghasilkan bakso berwarna abu-abu gelap. Bakso akibat perlakuan Tapioka $70 \%$ - ikan gabus $30 \%$ dan Tapioka $60 \%$ - ikan gabus $40 \%$ menghasilkan warna yang relatif bagus, mendekati warna bakso pada umumnya yaitu abu-abu terang. Terbentuknya warna keabu-abuan ini karena adanya reaksi pencoklatan non enzimatis antara asam amino dengan gula reduksi pada suhu pemanasan yang relatif tinggi (Saraswati. 1986), dalam penelitian ini bahan-bahan tersebut terkandung dalam bahan-bahan bakso, baik daging ikan gabus, tapioka maupun bumbu-bumbu yang ditambahkan.

\section{Kesukaan Aroma}

Kesukaan aroma bakso ikan gabus berkisar antara 3,1 yaitu cenderung agak tidak suka (tapioka $40 \%$ dan ikan gabus 60\%) hingga 6,4 yaitu antara suka hingga sangat suka (tapioka 70\% dan ikan gabus 30\%). Grafik hubungan antara perlakuan proporsi tapioka dan ikan gabus dengan Kesukaan aroma bakso ikan dapat dilihat pada Gambar 9.

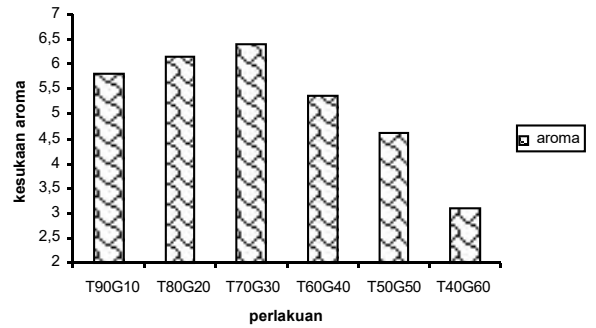

\section{Gambar 9. Hubungan perlakuan proporsi tapioka dan ikan gabus dengan kesukaan aroma}

Gambar 9 menunjukkan bahwa kesukaan aroma tertinggi adalah perlakuan Tapioka 70\% - ikan gabus $30 \%$. Bakso dengan kadar apioka yang cenderung tinggi masih lebih disukai aromanya daripada basko dengan kadar ikan gabus yang terlalu tinggi. Tabel 9 menunjukkan jumlah rangking kesukaan aroma akibat perlakuan proporsi ikan gabus dan tapioka.

Tabel 9 menunjukkan Tapioka 70\% - ikan gabus 30\% lebih disukai warnanya daripada perlakuan lainnya, sedangkan proporsi ikan gabus yang terlalu tinggi lebih tidak disukai aromanya. Hal ini karena aroma ikan gabus cenderung tajam (amis) sehingga beberapa panelis terutama yang kurang suka aroma ikan akan memberikan skor rendah. 
Tabel 9. Aroma Bakso Ikan Gabus

\begin{tabular}{|c|c|}
\hline Perlakuan & $\begin{array}{c}\text { Jumlah } \\
\text { rangking } \\
\text { kesukaan } \\
\text { aroma }\end{array}$ \\
\hline Tapioka $90 \%$ - ikan gabus $10 \%$ & $81.5 \mathrm{~b}$ \\
\hline Tapioka $80 \%$ - ikan gabus $20 \%$ & $93.0 \mathrm{ab}$ \\
\hline Tapioka $70 \%$ - ikan gabus $30 \%$ & $104.0 \mathrm{a}$ \\
\hline Tapioka $60 \%$ - ikan gabus $40 \%$ & $73.0 \mathrm{bc}$ \\
\hline Tapioka $50 \%$ - ikan gabus $50 \%$ & $44.5 \mathrm{c}$ \\
\hline Tapioka $40 \%$ - ikan gabus $60 \%$ & $24.0 \mathrm{~d}$ \\
\hline
\end{tabular}

Keterangan: Angka yang didampingi huruf yang sama menunjukkan tidak berbeda pada taraf $\alpha 5 \%$

\section{Kesukaan Rasa}

Kesukaan rasa bakso ikan gabus berkisar antara 3,25 yaitu antara agak tidak suka hingga ragu-ragu (tapioka $40 \%$ dan ikan gabus 60\%) hingga 5,55 yaitu antara agak suka hingga suka (tapioka $60 \%$ dan ikan gabus 40\%). Grafik hubungan antara perlakuan proporsi tapioka dan ikan gabus dengan Kesukaan rasa bakso ikan dapat dilihat pada Gambar 10.

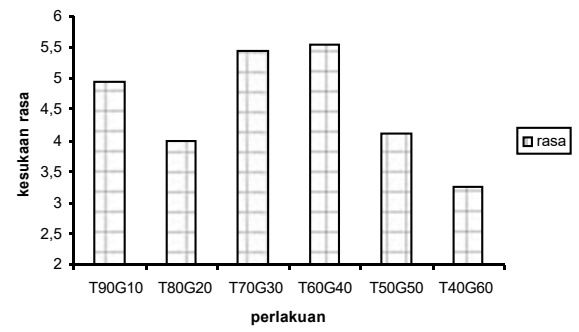

\section{Gambar 10. Hubungan antara perlakuan proporsi tapioka dan ikan gabus dengan kesukaan rasa}

Gambar 10 menunjukkan bahwa kesukaan rasa tertinggi adalah perlakuan Tapioka $60 \%$ - ikan gabus
40\% . Bakso dengan kadar tapioka yang cenderung tinggi masih lebih disukai rasanya daripada bakso dengan kadar ikan gabus yang terlalu tinggi. Tabel 10 menunjukkan jumlah rangking kesukaan rasa akibat perlakuan proporsi ikan gabus dan tapioka.

\section{Tabel 10. Rasa Bakso Ikan Gabus}

\begin{tabular}{|c|r|}
\hline Perlakuan & $\begin{array}{c}\text { Jumlah } \\
\text { rangking } \\
\text { kesukaan } \\
\text { rasa }\end{array}$ \\
\hline Tapioka $90 \%$ - ikan gabus $10 \%$ & $85.5 \mathrm{ab}$ \\
\hline Tapioka $80 \%$ - ikan gabus $20 \%$ & $56.0 \mathrm{~b}$ \\
\hline Tapioka $70 \%$ - ikan gabus 30\% & $99.5 \mathrm{a}$ \\
\hline Tapioka $60 \%$ - ikan gabus $40 \%$ & $103.0 \mathrm{a}$ \\
\hline Tapioka $50 \%$ - ikan gabus 50\% & $40.0 \mathrm{bc}$ \\
\hline Tapioka $40 \%$ - ikan gabus $60 \%$ & $36.0 \mathrm{c}$ \\
\hline
\end{tabular}

Keterangan: Angka yang didampingi huruf yang sama menunjukkan tidak berbeda pada $\operatorname{taraf} \alpha 5 \%$

Tampak pada Tabel 10 bahwa Tapioka $60 \%$ - ikan gabus $40 \%$ lebih disukai rasanya meskipun tidak berbeda dengan perlakuan Tapioka $70 \%$ - ikan gabus 30\% maupun Tapioka $90 \%$ - ikan gabus $10 \%$, sedangkan proporsi ikan gabus yang terlalu tinggi lebih tidak disukai rasanya. Cita rasa merupakan kombinasi antara rasa, flavor dan rangsangan mulut (Soekarto, 1985). Rasa bakso ikan gabus akiba tperlakuan Tapioka $60 \%$ - ikan gabus $40 \%$, perlakuan Tapioka 70\% - ikan gabus $30 \%$ maupun Tapioka 90\% - ikan gabus $10 \%$ adalah asin, sedikit manis akibat adanya ikan gabus dengan flavor 
yang tidak terlalu kuat, sedangkan ikan gabus yang terlalu banyak menghasilkan flavor ikan yang kuat sehingga megurangi selera panelis.

\section{Pengambilan Keputusan}

Analisis pengambilan keputusan menggunakan metode Indeks Efektivitas. Pertimbangan penggunaan metode tersebut adalah:

1. Karena bakso ikan sudah umum dikonsumsi sehingga panelis dapat menentukan bobot kepentingan.

2. Perlakuan berpengaruh terhadap semua parameter yang ada baik untuk parameter fisikokimia dan parameter organoleptik, sehingga mengindikasikan bahwa terdapat parameter yang lebih penting dan kurang penting.

Berdasarkan perhitungan dengan menggunakan metode Indeks Efektivitas, maka diperoleh bahwa perlakuan terbaik untuk parameter organoleptik adalah tapioka $70 \%$ dan ikan gabus $30 \%$ dengan nilai hasil tertinggi yaitu sebesar 0,914498. Sedangkan perlakuan terbaik untuk parameter fisikokimia adalah tapioka $40 \%$ dan ikan gabus $60 \%$ dengan nilai hasil tertinggi sebesar 0,719048 .

Perlakuan tapioka $70 \%$ dan ikan gabus 30\% menghasilkan kadar air $49,27 \%$, kadar abu $10,365 \mathrm{mg} / 100 \mathrm{~g}$, tekstur 13,05 N, kadar pati 18,805\%, kadar lemak 1,7675\%, kadar protein $22,8275 \%$, kesukaan : warna 5,95 (mendekati suka), kekenyalan 5,35 (antara agak suka sampai suka), aroma 6,4 (antara suka sampai sangat suka) dan rasa 5,45 (antara agak suka sampai suka). Perlakuan tapioka $40 \%$ dan ikan gabus $60 \%$ menghasilkan kadar air $53,21 \%$, kadar abu $10,5175 \mathrm{mg} / 100$ $\mathrm{g}$, tekstur $17,025 \mathrm{~N}$, kadar pati $14,7 \%$, kadar lemak 1,9825\%, kadar protein $27,205 \%$, kesukaan : warna 4,95 (mendekati agak suka), kekenyalan 6,05 (mendekati suka), aroma 3,1 (cenderung agak tidak suka) dan rasa 3,25 (cenderung agak tidak suka).

Berdasarkan hal diatas ternyata bahwa kandungan gizi bakso akibat perlakuan tapioka $40 \%$ dan ikan gabus $60 \%$ lebih tinggi daripada perlakuan tapioka $70 \%$ dan ikan gabus $30 \%$, namun ternyata panelis lebih menyukai bakso akibat perlakuan tapioka 70\% dan ikan gabus 30\%. Karena bakso ikan gabus direncanakan akan diproduksi dalam suatu skala usaha (merupakan teknologi terapan) maka yang lebih diutamakan adalah kesukaan panelis yang mewakili konsumen. Meskipun kandungan gizi sangat bagus namun jika konsumen tidak suka, maka tentunya suatu produk pangan tidak layak secara finansial untuk diproduksi. Dengan demikian perlakuan terbaik yang dipilih adalah perlakuan tapioka $70 \%$ dan ikan gabus $30 \%$.

\section{Kelayakan Finansial}

Analisis kelayakan finansial didasarkan pada beberapa asumsi berikut:

1. Usaha bakso ikan gabus merupakan usaha skala kecil

2. Kapasitas bahan baku ikan gabus $50 \mathrm{~kg}$ / hari dan tapioka $70 \mathrm{~kg} /$ hari

3. Waktu produksi 25 hari kerja / bulan atau 300 hari kerja / tahun 
4. Usia guna proyek 10 tahun

5. Tidak ada persediaan produk, semua langsung dijual begitu produk jadi

6. Lokasi perusahaan dekat sungai yang menghasilkan ikan gabus, di desa Pager, Pasuruan

7. Wilayah pemasaran adalah daerahdaerah sekitar Pasuruan.

8. Kapasitas produksi $118 \mathrm{~kg}$ bakso ikan gabus / hari dalam kemasan berisi 500 gram.

9. Pinjaman bank sebesar $70 \%$ dari total modal

10. Suku bunga pinjaman $15 \%$ per tahun

11. Suku bunga deposito $9 \%$ per tahun

12. Harga jual naik 4\%/tahun mulai tahun ke 3

13. Penjualan $80 \%$ tahun ke $1,90 \%$ tahun ke2 dan $100 \%$ tahun ke 3-10

14. Pengeluaran /tahun naik $4 \%$

15. Rendemen sebesar 98,33\% (berat produk $118 \mathrm{~kg}$ dibagi dengan berat bahan baku yaitu baku ikan gabus $50 \mathrm{~kg}$ dan tapioka $70 \mathrm{~kg}$ )

Hasil perhitungan Harga Pokok Produksi sebesar Rp. 4.202,25 / 500 gram dan harga jual sebesar $\mathrm{Rp}$ 6.093,27 dengan mengambil keuntungan 45\%. PBP sebesar 4,941 tahun (layak karena kurang dari 10 tahun), Net $\mathrm{BC}$ ratio $=1,223$ (layak karena $<1$ ), $\mathrm{RCR}=1,372$ (layak karena $<1), \mathrm{NPV}=$ Rp. 8.659.111,91, IRR = $16,53 \%$ (layak karena lebih besar dari suku bunga deposito), BEP $=4.851,86$ unit atau senilai Rp. 37.775.000,08 atau $6,9 \%$.

Apabila asumsi penjualan diturunkan, yaitu penjualan sebesar
$70 \%$ tahun ke 1, 80\% tahun ke- 2 dan 95\% tahun ke $3-10$, maka Payback Period menjadi 8,1 tahun (lebih kecil dari usia guna proyek tetapi pada kenyataannya terlalu lama karena pada umumnya suatu usaha kecil mengharapkan dalam kurun waktu paling lama setengah dari usia guna proyek, modal sudah kembali), Net $\mathrm{BCR}=0,45$ (tidak layak karena bernilai $<1$ ), $\mathrm{RCR}=1,289$ (layak karena bernilai $>1$ ),

IRR bernilai negatif sehingga tidak layak, NPV pada suku bunga 15\% sebesar Rp. 563.490.522,36 (bernilai negatif sehingga tidak layak) sedangkan BEP = 4.851,86 unit atau Rp. 37.775.000,08 atau $6,9 \%$.

Apabila biaya produksi naik, yaitu biaya-biaya variabel naik dengan perincian berikut :

\section{Tabel 11. Kenaikan Biaya Produksi}

\begin{tabular}{|l|r|r|}
\hline \multicolumn{1}{|c|}{ Jenis } & \multicolumn{1}{c|}{$\begin{array}{c}\text { Unit/ } \\
\text { produksi }\end{array}$} & $\begin{array}{l}\text { Harga } \\
\text { Satuan } \\
\text { (Rp) }\end{array}$ \\
\hline ikan gabus $(\mathrm{kg})$ & 50 & $7.000,00$ \\
\hline tapioka $(\mathrm{kg})$ & 70 & $5.000,00$ \\
\hline garam $(\mathrm{kg})$ & 1 & $1.500,00$ \\
\hline bawang putih $(\mathrm{kg})$ & 3 & $8.000,00$ \\
\hline merica bubuk $(\mathrm{kg})$ & 0,5 & $6.000,00$ \\
\hline bawang merah $(\mathrm{kg})$ & 3 & $7.000,00$ \\
\hline air (liter) & 300 & 75 \\
\hline minyak tanah (liter) & 10 & $2.800,00$ \\
\hline plastik sablon & & \\
kapasitas 500 & 236 & 275 \\
\hline bensin (liter) & 5 & $4.800,00$ \\
\hline tenaga kerja & 4 & $27.500,00$ \\
\hline pemasaran & 1 & $22.500,00$ \\
\hline
\end{tabular}

Maka diperoleh kriteria-kriteria kelayakan finansial sebagai berikut : Payback Period 17,846 tahun (tidak layak karena lebih dari usia guna proyek), Net $\mathrm{BC}$ rati $\mathrm{o}=-0,163$ (tidak 
layak karena lebih kecil dari 1), RCR = 1,204 (layak karena bernilai $>1$ ), IRR = bernilai negatif sehingga tidak layak, NPV pada suku bunga 15\% sebesar Rp. $-1.050 .161 .569,18, \quad \mathrm{BEP}=5.664,75$ unit atau Rp. 89.172.697,25 atau $8,00 \%$.

\section{KESIMPULAN DAN SARAN}

\section{Kesimpulan}

Kesimpulan dari hasil penelitian ini adalah:

- perlakuan proporsi tapioka dan daging ikan gabus berpengaruh terhadap kadar air, kadar abu, tekstur, kadar protein, kadar lemak, kadar pati, kesukaan : warna, kekenyalan, aroma dan rasa.

- Perlakuan terbaik adalah perlakuan tapioka $70 \%$ dan ikan gabus $30 \%$ dengan kadar air 49,27\%, kadar abu $10,365 \mathrm{mg} / 100 \mathrm{~g}$, tekstur $13,05 \mathrm{~N}$, kadar pati 18,805\%, kadar lemak $1,7675 \%$, kadar protein $22,8275 \%$, kesukaan : warna 5,95 (mendekati suka), kekenyalan 5,35 (antara agak suka sampai suka), aroma 6,4 (antara suka sampai sangat suka) dan rasa 5,45 (antara agak suka sampai suka).

- Kapasitas produksi 118 kg bakso ikan gabus / hari layak secara finansial dengan kriteria-kriteria sebagai berikut: PBP sebesar 4,941 tahun, Net $\mathrm{BC}$ ratio= $1,223, \mathrm{RCR}=$ 1,372, NPV (pada suku bunga pinjaman $15 \%)=\mathrm{Rp}$. 8.659.111,91, IRR $=16,53 \%, \mathrm{BEP}=$ 4.851,86 unit atau Rp. 37.775.000,08 atau $6,9 \%$.

\section{Saran}

Saran bagi hasil penelitian ini adalah:

- perlu diteliti upaya reduksi aroma ikan gabus, karena aroma ikan gabus lebih tajam dibandingkan dengan aroma ikan-ikan lainnya baik dengan perlakuan fisik ataupun kimia

\section{DAFTAR PUSTAKA}

Anonymous, 1997. Buku Pedoman Pengenalan Sumber

Perikanan Air Tawar. Dinas

Perikanan Propinsi Dati I Jatim. Surabaya

AOAC. 1990. Official Methods of Analysis of the Association of Official Analytical Chemists. Association of Official Analytical Chemists, Washington D.C.

Djuhanda, T. 1981. Dunia Ikan. Armico. Bandung.

Gaspersz, V. 1992. Teknik Analisis dalam Penelitian Percobaan. Tarsito. Bandung

Hadiwiyoto, $1993 \quad$ Teknologi Pengolahan Hasil Perikanan Jilid I. Pen. Liberty. Jogjakarta

Hardoko, 1994. Pembuatan Fish Cake (Kamaboko) dari Daging Ikan Tengiri dengan Tepung Gandum dan Tepung Sagu. Buletin Ilmiah Perikanan. Faperik Unibraw Malang, III : p.63-72. 
Saraswati, 1986. Pembuatan Keripik Ikan Tengiri. PT. Bharata Karya Aksara. Jakarta.

SNI. 1995. Bakso Ikan. Dewan Standarisasi Nasional. Jakarta.

Sudarminto dan Yuwono, 2002.Analisis Karakteristik Fisik Bahan Pangan. Jurusan THP Fakultas Teknologi Pertanian Univ. Brawijaya. Malang
Suprayitno, E. 2003. Potensi Serum Albumin dari Ikan Gabus. Kompas Cyber Media

4 Januari 2003.

Wibowo,S. 1999. Pembuatan Bakso Ikan dan Bakso Daging. Pen. Swadaya. Jakarta. 